\title{
Distribution of Chromaffin Secretory Vesicles, Acetylcholinesterase, and Lysosomal Enzymes in Sucrose and Percoll Gradients
}

\author{
MANFRED GRATZl. \\ Abteilung Klinische Morphologie, Universität Ulm, D-7900 Ulm, Federal Republic of Germany
}

Received December 28, 1983

\begin{abstract}
Crude chromaffin secretory vesicles, obtained by differential centrifugation, were further purified on isotonic (Percoll) gradients. The chromaffin vesicle fractions recovered from the gradients contain acetylcholinesterase as well as lysosomal enzymes. With the aid of a subsequent sucrose gradient lysosomal enzymes could be removed from chromaffin vesicle fractions, but not acetylcholinesterase. This suggests that lysosomal enzymes do not pass through the chromaffin vesicles during the biogenesis of lysosomes but acetylcholinesterase does. 1984 Academic Press, Inc.
\end{abstract}

KEY WORDS: chromaffin vesicles; acetylcholinesterase; lysosomal enzymes; subcellular fractions.

Lysosomal enzymes and acetylcholinesterase have been reported to be secreted from perfused adrenals as well as from cultured chromaffin cells (1-5). Subcellular fractionation and separation of crude chromaffin secretory vesicles on Percoll density gradients have indicated that both lysosomal enzymes and acetylcholinesterase are present in chromaffin vesicle fractions $(6,7)$. Thus it seems that chromaffin vesicles contain these enzymes and may therefore act as transport systems for cell membrane and lysosomal components as well as the "natural" secretory products of the chromaffin cell.

In the hepatocyte, 5'-nucleotidase and adenylate cyclase, two typical cell membrane enzymes, have been found to be part of the secretory vesicles, a fact which is compatible with their insertion into the cell membrane during exocytosis (8-11). Also, the transfer of lysosomal enzymes to lysosomes in fibroblasts possibly involves a pathway including secretion or transport to the cell membrane followed by reuptake (cf. Ref. (12)).

To find out whether acetylcholinesterase as well as lysosomal enzymes are indeed constituents of the chromaffin vesicle and might therefore be involved in the biogenesis of the cell membrane and the lysosomes, we have first purified crude chromaffin vesicles on Percoll gradients and subsequently put the secretory vesicle fractions recovered from these gradients on sucrose gradients. The careful analysis of five different acid hydrolases, acetylcholinesterase, and several other markers in the gradients revealed that chromaffin secretory vesicles contain acetylcholinesterase but not lysosomal enzymes.

\section{MATERIAL AND METHODS}

Homogenization of adrenal medullary tissue, differential centrifugation, and densitygradient centrifugation in Percoll media were carried out as previously described (7). Briefly, bovine adrenal glands were transported from the local slaughterhouse to the laboratory in an ice-cold medium containing $20 \mathrm{mM}$ phosphate (pH 7.4, adjusted with $\mathrm{NaOH}$ ), $0.9 \%$ $\mathrm{NaCl}, 1 \mathrm{~mm}$ EDTA, and $1 \mathrm{mM}$ EGTA. The medullae were cut out and placed into the isolation medium containing $20 \mathrm{mM}$ Mops' (pH 7.0, adjusted with $\mathrm{KOH}$ ), 1 mM EGTA, and sucrose to give a final osmolality of 420

\footnotetext{
${ }^{1}$ Abbreviation used: Mops, 4-morpholinepropanesulfonic acid.
} 
mosmol $/ \mathrm{kg}$. The medullae $(20 \% \mathrm{w} / \mathrm{v})$ were minced into small pieces and homogenized in a loose-fitting Teflon-to-glass homogenizer by three downward strokes. To remove unbroken tissue the homogenate was filtered through three layers of cheesecloth. The resulting suspension was first centrifuged at $2200 g_{\mathrm{av}}$ for $10 \mathrm{~min}$. The low-speed pellet P1 was discarded and the supernatant S1 was centrifuged at $12,000 g_{\mathrm{av}}$ for $20 \mathrm{~min}$. The pellet obtained from $8 \mathrm{~g}$ of tissue was resuspended in $1 \mathrm{ml}$ isolation medium ( $\mathrm{P} 2$, crude chromaffin vesicles). Percoll ( $50 \%$ ) in isolation medium was prepared either by dialysis (7) or by addition of an equal volume of twiceconcentrated isolation medium to $1 \mathrm{vol}$ of Percoll (density $1.132 \mathrm{~g} / \mathrm{ml}$ ). One milliliter of the crude chromaffin vesicle fraction (P2) was mixed with $8 \mathrm{ml} 50 \%$ Percoll in isolation medium prepared as described above and centrifuged at $35,000 \mathrm{~g}_{\mathrm{av}}$ for $30 \mathrm{~min}$ in a fixed-angle rotor (Beckman TFT, 65.13). Purified secretory vesicles were recovered from the Percoll gradient (fractions 1-18). Percoll was removed using a Sephacryl 2000 column equilibrated with isolation medium. The vesicles were then concentrated by centrifugation $\left(12,000 \mathrm{~g}_{\mathrm{av}}\right.$ for $\left.20 \mathrm{~min}\right)$ and resuspended in a small volume of isolation medium (fraction $\mathrm{SV}$, about $40 \mathrm{mg}$ protein $/ \mathrm{ml}$ ).

A $0.3-\mathrm{ml}$ amount of the secretory vesicle fractions (SV) was placed on discontinuous sucrose gradients. Their composition (in 14$\mathrm{ml}$ tubes) was $2 \mathrm{ml}$ of $2.4 \mathrm{M} ; 1 \mathrm{ml}$ each of $2.3,2.2,2.1,2.0,1.9,1.8,1.7$, and $1.6 \mathrm{M}$; and $0.9 \mathrm{ml}$ each of 1.5 and $0.86 \mathrm{M}$ sucrose in $20 \mathrm{~mm}$ Mops (pH 7.0), $1 \mathrm{mM}$ EGTA. Centrifugation was carried out at $40,000 \mathrm{rpm}$ for $3 \mathrm{~h}$ in a SW $40 \mathrm{Ti}$ rotor. Fractions of 8 drops were collected from the gradients by means of a peristaltic pump.

Protein, acetylcholinesterase, and absorbance at $280 \mathrm{~nm}$ were determined as described recently $(7,13)$. The details of the methods used in the assays for five different acid hydrolases (14-16) are given in Table 1. Cytochrome $b_{561}$ was estimated from the reduced minus oxidized difference spectra
(17). ATPases were measured as described $(18,19)$. Substances were obtained from the following manufacturers: substrates for the acid hydrolases, Serva, Heidelberg; Percoll, Pharmacia, Freiburg; Vanadate-free ATP and ouabain, Sigma, Munich. All other chemicals were of the purest grade commercially available.

\section{RESULTS AND DISCUSSION}

The isolation of pure and stable subcellular organelles is a prerequisite for biochemical studies on the compositions, properties, and functions of these structures. Secretory vesicles are characterized by high amounts of intravesicular substances (secretory products). During sucrose-gradient centrifugation secretory vesicles are exposed to hypertonic media, which probably causes the instability of the isolated material. To circumvent this disadvantage secretory vesicles from the neurohypophysis and adrenal medulla have been isolated on isotonic continuous gradients using Percoll as gradient material $(6,7,20,21)$. The main contaminants of crude secretory vesicle fractions (i.e., those obtained by differential centrifugation) are mitochondria, which can be completely removed using such gradients. The vesicles obtained are stable and have successfully been used in studies concerned with the analysis of proton, solium, and calcium transport $(6,7,13,20$, 22-24).

However, crude secretory vesicles (fraction P2) also contain lysosomal enzymes (e.g., $55.5 \% \pm 10.1, n=11$, of the activity of aryl sulfatase present in the homogenate of bovine adrenal medullary homogenates). Reports from several laboratories have indicated that lysosomal enzyme activities are found also in secretory vesicle fractions after further purification on Percoll gradients $(6,20,24)$. The determination of $\beta$-gluconidase and $\beta$ hexosaminidase in Percoll gradients (Fig. 1) shows that a part of these lysosomal enzyme activities is in fact centered around fraction 8 , which also contains the markers for chro- 
TABLE 1

ANALytical Procedures for Enzyme Assays of Lysosomal Enzymes

\begin{tabular}{|c|c|c|c|c|c|c|c|}
\hline Enzyme & Substrate & Buffer & $\begin{array}{l}\text { pH/final } \\
\text { volume } \\
\text { (ml) }\end{array}$ & Addition & Manipulation & $\begin{array}{l}\text { Wavelength for } \\
\text { colorimetric } \\
\text { determination } \\
\text { (nm) }\end{array}$ & Reference \\
\hline $\begin{array}{l}\text { Acid phosphatase } \\
\text { (EC } 3.1 .3 .2 \text { ) }\end{array}$ & $\begin{array}{l}5.5 \text { mM Nitrophenyl } \\
\text { phosphate }\end{array}$ & $\begin{array}{l}\text { Acetate } \\
\qquad(50 \mathrm{mM})\end{array}$ & $5.0 / 0.2$ & $\begin{array}{l}0.1 \% \text { Triton } X-100 \\
\pm 7.5 \mathrm{mM} \text { tatrate }\end{array}$ & $\begin{array}{l}\text { Add I ml of glycine }(0.53 \mathrm{M}) \\
\mathrm{Na}_{2} \mathrm{CO}_{3}(0.34 \mathrm{M}), \mathrm{NaCl} \\
(0.27 \mathrm{M}), \mathrm{pH} 10.7 \\
\text { centrifuge }\end{array}$ & 405 & (14) \\
\hline $\begin{array}{l}\text { Aryl sulfatase } \\
\text { (EC 3.1.6.1) }\end{array}$ & $\begin{array}{l}10 \mathrm{mM} \text { Nitro- } \\
\text { catechol sulfate }\end{array}$ & $\begin{array}{l}\text { Acetate } \\
\qquad(200 \mathrm{~mm})\end{array}$ & $5.0 / 0.2$ & $\begin{array}{l}0.1 \% \text { Triton } X-100 \\
\mathrm{NaCl}(0.5 \mathrm{M})\end{array}$ & $\begin{array}{l}\text { Add } 1 \mathrm{ml} \text { of } 10 \% \mathrm{TCA} \\
\text { centrifuge; add } 1 \mathrm{ml} \text { of } \\
\mathrm{NaOH}(2.5 \mathrm{M}) \text { to } \\
\text { supernatant }\end{array}$ & 515 & (15) \\
\hline $\begin{array}{r}\beta \text {-Galactosidase } \\
(\text { EC 3.2.1.23) }\end{array}$ & $\begin{array}{l}5 \text { mM Nitrophenyl } \\
\text { galactoside }\end{array}$ & $\begin{array}{l}\text { Acetate } \\
\qquad(100 \mathrm{mM})\end{array}$ & $5.0 / 0.2$ & $\begin{array}{l}0.1 \% \text { Triton } \mathrm{X}-100 \\
\mathrm{NaCl}(0.1 \mathrm{M})\end{array}$ & $\begin{array}{l}\text { Add I ml glycine }(0.25 \mathrm{M}) \\
\text { pH } 9.8 ; \text { centrifuge }\end{array}$ & 405 & $(14,16)$ \\
\hline $\begin{array}{l}\beta \text { - } N \text {-Acetyl } \\
\text { glucosaminidase } \\
\text { (EC 3.2.1.30) }\end{array}$ & $\begin{array}{l}10 \mathrm{~mm} \text { Nitrophenyl- } \\
N \text {-acetyl- } \beta \text { - } \\
\text { glucosaminide }\end{array}$ & $\begin{array}{l}\text { Citrate } \\
\qquad(200 \mathrm{~mm})\end{array}$ & $4.5 / 0.1$ & $\begin{array}{l}0.2 \% \text { Triton } \mathrm{X}-100 \\
\mathrm{NaCl}(0.2 \mathrm{M}) \\
\mathrm{BSA}(0.01 \%)\end{array}$ & $\begin{array}{l}\text { Add } 1 \mathrm{ml} \text { glycine }(0.25 \mathrm{M}) \\
\text { pH } 9.8 ; \text { centrifuge }\end{array}$ & 405 & (14) \\
\hline $\begin{array}{l}\beta \text {-Glucuronidase } \\
\text { (EC 3.2.1.31) }\end{array}$ & $\begin{array}{l}2 \text { mM Nitrophenyl } \\
\text { glucuronide }\end{array}$ & $\begin{array}{l}\text { Acetate } \\
\qquad(50 \mathrm{mM})\end{array}$ & $5.0 / 0.2$ & $0.1 \%$ Triton $X-100$ & $\begin{array}{l}\text { Add } 1 \mathrm{ml} \text { of glycine }(0.53 \mathrm{M}), \\
\mathrm{Na}_{2} \mathrm{CO}_{3}(0.34 \mathrm{M}), \mathrm{NaCl} \\
(0.27 \mathrm{M}), \mathrm{pH} 10.7 \\
\text { centrifuge }\end{array}$ & 405 & (14) \\
\hline
\end{tabular}

Note. All incubations were carried out at $30^{\circ} \mathrm{C}$. EC in the first column refers to the enzyme classification by the Commission on Enzymes of the International Union of Biochemistry, 
maffin secretory vesicle contents $(7,13)$. The same fractions also contain acetylcholinesterase (Fig. 1), an enzyme which has been reported to be present in chromaffin secretory vesicles (7).

Both lysosomal enzymes as well as acetylcholinesterase have been shown to be secreted from perfused adrenals (1-3) and a corelease of acetylcholinesterase and catecholamines has been observed from chromaffin cells in culture $(4,5)$. Thus, if both types of enzymes are actually present within the chromaffin secretory vesicles the parallel secretion of these enzymes together with catecholamines could be feasible.

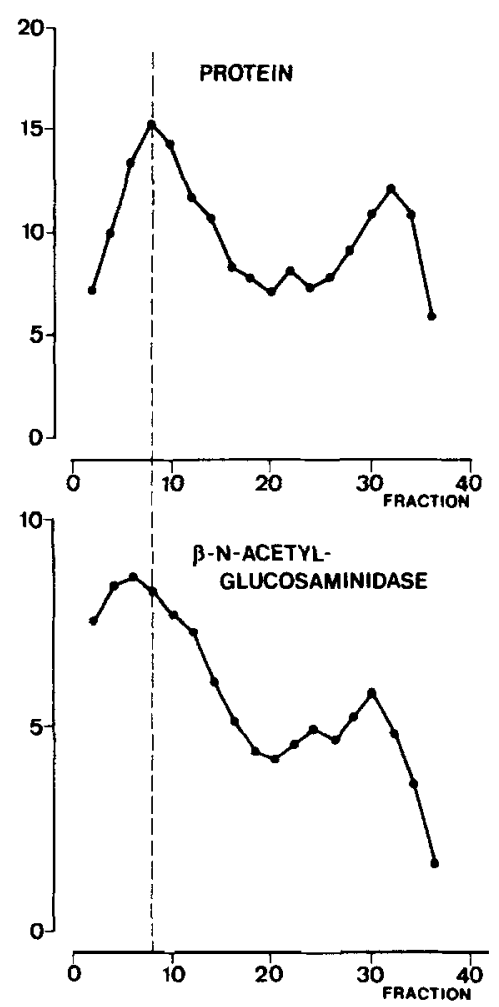

As a further test for the colocation of lysosomal enzymes and acetylcholinesterase within chromaffin secretory vesicles, we have put the secretory vesicle fractions recovered from the Percoll gradients described above on sucrose gradients (Fig. 2). In these gradients the distribution of acetylcholinesterase, cytochrome $b_{561}$, and $\mathbf{M g}^{2+}$-ATPase was similar to that of the absorbance at $280 \mathrm{~nm}$, which was taken to conveniently locate secretory vesicle contents (catecholamines plus nucleotides) of chromaffin vesicles (compare Refs. (7) and (13)). By contrast the distribution of five lysosomal enzymes, namely aryl sulfatase, $\beta$-glucuronidase, $\beta$-hexosaminidase,

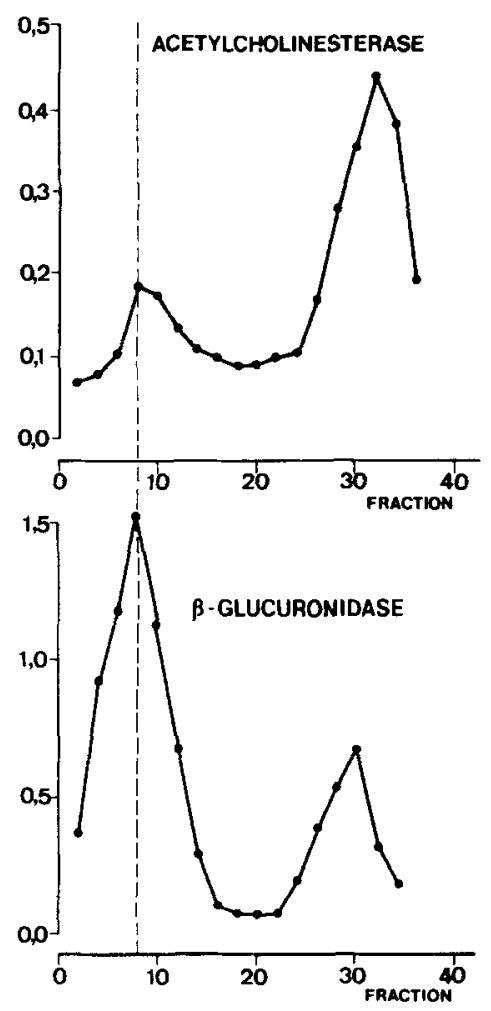

FIG. 1. Distribution of markers in fractions from Percoll gradients. Crude chromaffin vesicles (fraction P2) obtained by differential centrifugation $\left(12,000 \mathrm{gav}_{\mathrm{av}}\right.$ for $20 \mathrm{~min}$ were placed on a $50 \%$ Percoll gradient. After centrifugation in a fixed-angle rotor (TFT, 65.13) at $35,000 \mathrm{~g}_{\mathrm{av}}$ for $30 \mathrm{~min}$, fractions were collected from the bottom and analyzed. Protein is given as $\mathrm{mg} \times \mathrm{ml}^{-1}$, acetylcholinesterase as $\mu \mathrm{mol}$ acetylthiocholine hydrolyzed $\times \min \times \mathrm{ml}^{-1}, \beta$-N-acetylglucosaminidase and $\beta$-glucuronidase as $\mu$ mol product formed $\times 30$ $\min ^{-1} \times \mathrm{ml}^{-1}$. The vertical dashed line marks the protein peak which contains the highest amount of ascorbate, adrenalin, and noradrenalin (7). 

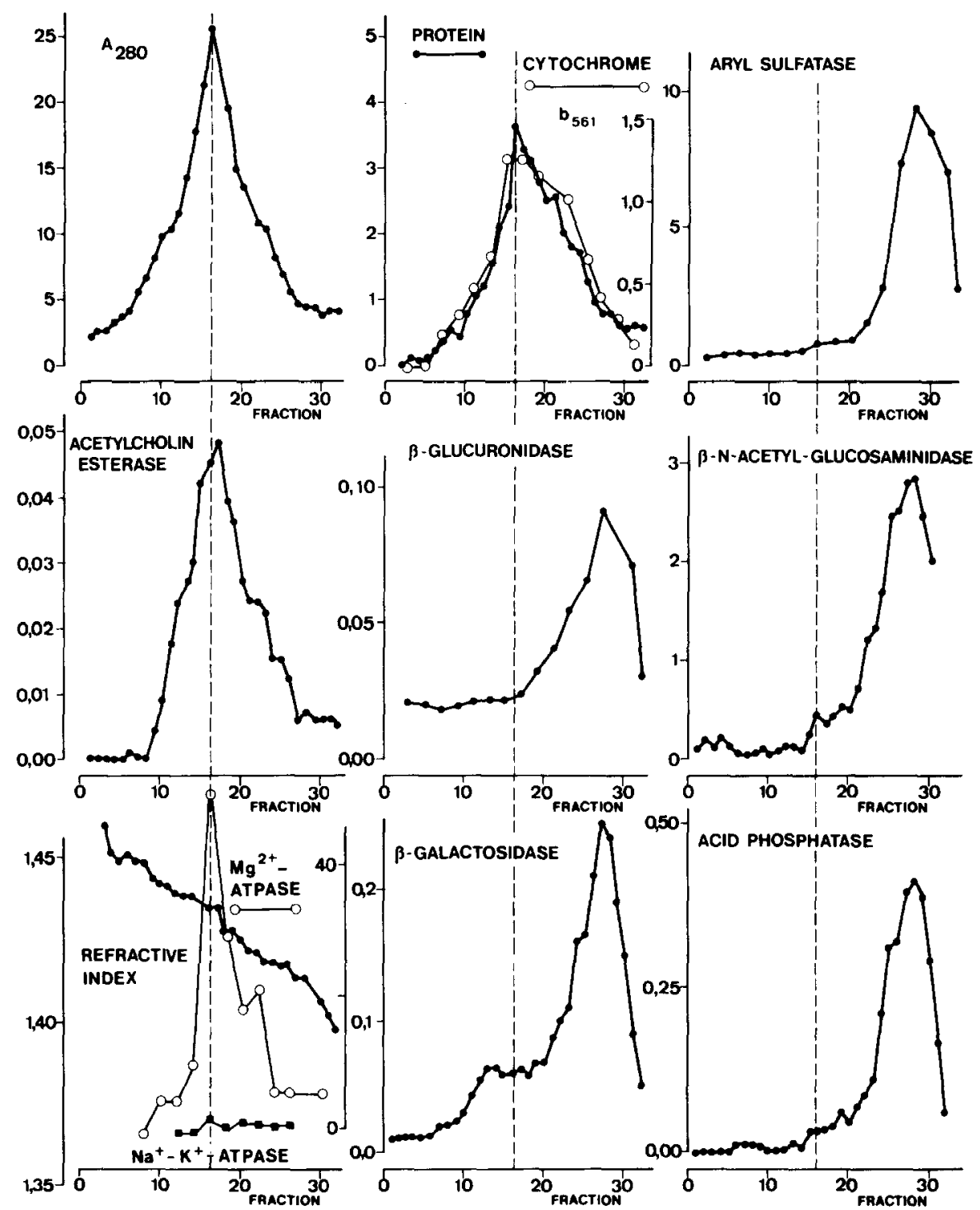

FIG. 2. Distribution of markers in fractions recovered from sucrose gradients. Purified chromaffin vesicles (fraction SV) recovered from the Percoll gradient were placed on a sucrose gradient (see refractive index). After centrifugation in a SW 40 rotor $\left(368,000 g_{\max }\right.$ for $\left.180 \mathrm{~min}\right)$ fractions were collected from the bottom and analyzed. Protein is given as $\mathrm{mg} \times \mathrm{ml}^{-1}$, catecholamines plus nucleotides as absorbance at $280 \mathrm{~nm} \times \mathrm{ml}^{-1}$, acetylcholinesterase as $\mu \mathrm{mol}$ acetylthiocholine hydrolyzed $\times \min ^{-1} \times \mathrm{ml}^{-1}$, lysosomal enzymes as $\mu \mathrm{mol}$ product formed $\times 30 \mathrm{~min}^{-1} \times \mathrm{ml}^{-1}$, ATPases as nmol ADP formed $\times \min ^{-1} \times \mathrm{ml}^{-1}$, and cytochrome $b_{561}$ as $\mathrm{nmol} \times \mathrm{ml}^{-1}$. The vertical dashed line marks the protein peaks which coincides with that of $A_{280}$, cytochrome $b_{561}$, acetylcholinesterase, and $\mathrm{Mg}^{2+}-\mathrm{ATPase}$.

$\beta$-galactosidase, and acid phosphatase, displayed a completely different pattern. From these results the following conclusions can be drawn: First, the lysosomal enzymes are located in a compartment different from chromaffin vesicles, whereas acetylcholines- 
terase is contained within these structures. Second, the strategy to use a Percoll gradient as well as a sucrose gradient successively allows the removal first of mitochondria, then of lysosomes, a fact which might be advantageous as a basis for the isolation of pure lysosomes from this tissue.

Earlier attempts to directly put crude chromaffin secretory vesicles on sucrose gradients to remove lysosomal enzymes from the fractions did not allow a ready interpretation of the results because the distribution for these enzymes was bimodal and the chromaffin vesicle fractions obtained still contained a certain percentage of lysosomal enzymes $(25,26)$. Furthermore, a direct comparison of chromaffin secretory vesicle fractions prepared on different types of gradients revealed that the activity of $\beta$-glucuronidase was still substantial in fractions purified on sucrose gradients (6).

The data presented in this report on the removal of lysosomal enzymes from chromaffin vesicle fractions using, successively, two types of density gradients definitely rule out a colocation of these enzymes in chromaffin secretory vesicles and strongly argue against a role for these structures in the biogenesis of lysosomes. Similar observations have been made in neurohypophysial secretory vesicles $(20,24)$. However, the colocation of cell membrane components within chromaffin vesicles in conjunction with cotransport studies on the intact tissue as well as on chromaffin cells in culture suggest a participation of chromaffin secretory vesicles in the biogenesis of the cell membrane. In the hepatocyte such a process has been described for 5'-nucleotidase and adenylate cyclase (811). The presence of adenylate cyclase has also been reported in chromaffin secretory vesicles (27). In further studies (28) it had been argued that this enzyme distributes in sucrose gradients in the same way as does acetylcholinesterase, which was at that time accepted to be an exclusive marker for cell membranes. However, the present data on acetylcholinesterase distribution in different types of density gradients show that this argument may no longer be valid.

Obviously there are several cell membrane markers present in chromaffin vesicles. In addition to the examples of adenylate cyclase and acetylcholinesterase discussed above, the $\alpha$-bungarotoxin-binding part of the acetylcholine receptor (29) and sodium-calcium exchange activity have also been observed in chromaffin secretory vesicles $(13,22,30)$. The finding on the absence of $\mathrm{Na}^{+}-\mathrm{K}^{+}$-ATPase activity in the chromaffin vesicle fractions (Fig. 2) is not surprising. The subunits of this enzyme after biosynthesis are processed in different ways. The $\beta$ subunit is synthesized at the endoplasmic reticulum and traverses the Golgi but the $\alpha$ subunit appears to be synthesized on free polysomes and discharged to the cytoplasm (cf. Ref. (31)). Lack of enzyme activity in chromaffin vesicles therefore only means that no mature (assembled) $\mathrm{Na}^{+}-\mathrm{K}^{+}$-ATPase exists in these structures.

\section{ACKNOWLEDGMENTS}

The author thanks Mrs. Monica Elis, Mrs. Inge Lind, Miss Sabine Schatto, and Mrs. Brigitte Mader for their excellent technical assistance and help during preparation of the manuscript. This work was supported by the Deutsche Forschungsgemeinschaft (Gr 681/2-1).

\section{REFERENCES}

1. Schneider, F. H. (1968) Biochem. Pharmacol. 17, 848-851.

2. Schneider, F. H. (1970) Biochem. Pharmacol. 19, 833-847.

3. Chubb, I. W., and Smith, A. D. (1975) Proc. Roy. Soc. (London) 191, 263-269.

4. Mizobe, F., and Livett, B. G. (1980) J. Neurochem. 35, 1469-1473.

5. Mizobe, F., and Livett, B. G. (1983) J. Neurosci. 3, 871-876.

6. Carty, S. E., Johnson, R. G., and Scarpa, A. (1980) Anal. Biochem. 106, 438-445.

7. Gratzl, M., Krieger-Brauer, H., and Ekerdt, R. (1981) Biochim. Biophys. Acta 649, 355-366.

8. Farquhar, M. G., Bergeron, J. J. M., and Palade, G. E. (1974) J. Cell Biol. 60, 8-25.

9. Little, J. S., and Widnell, C. C. (1975) Proc. Natl. Acad. Sci. USA 72, 4013-4017.

10. Cheng, H., and Farquhar, M. G. (1976) J. Cell Biol. $70,660-670$. 
11. Cheng, H., and Farquhar, M. G. (1976) J. Cell Biol. 70, 670-684.

12. Hasilik, A. (1980) Trends in Biochem. Sci. 5, 237240.

13. Krieger-Brauer, H., and Gratzl, M. (1982) Biochim. Biophys. Acta 691, 61-70.

14. Hall, C. W., Liebaers, I., Di Natale, P., and Neufeld, E. F. (1978) in Methods in Enzymology (Ginsburg, V., ed.), Vol. 50, pp. 439-456, Academic Press, New York.

15. Bowers, W. E., Finkenstaedt, J. T., and De Duve, C. (1967) J. Cell Biol. 32, 325-337.

16. Meisler, M. (1972) in Methods in Enzymology (Ginsburg, V., ed), Vol. 28, pp. 820-824, Academic Press, New York.

17. Silsand, T., and Flatmark, T. (1974) Biochim. Biophys. Acta 395, 257-266.

18. Saermark, T., and Vilhardt, H. (1979) Biochem. J. 181, 321-330.

19. Saermark, T., and Thorn, N. A. (1982) Cell Calcium 5, 561-581.

20. Gratzl, M., Torp-Pedersen, C., Dartt, D., Treiman, M., and Thorn, N. A. (1980) Hoppe-Seylers Z. Physiol. Chem. 361, 1615-1628.
21. Terland, O., Flatmark, T., and Kryvi, H. (1979) Biochim. Biophys. Acta 553, 460-468.

22. Krieger-Brauer, H., and Gratzl, M. (1981) FEBS Lett. 133, 244-246.

23. Saermark, T., Krieger-Brauer, H., Thorn, N. A., and Gratzl, M. (1983) Biochim. Biophys. Acta 727, 239-245.

24. Saermark, T., Thorn, N. A., and Gratzl, M. (1983) Cell Calcium 4, 151-170.

25. Smith, A. D., and Winkler, H. (1966) J. Physiol. 183, 179-188.

26. Schneider, F. H. (1970) Biochem. Pharmacol. 19, 819-831.

27. Zinder, O., Menard, R., Lovenberg, W., and Pollard, H. B. (1977) Biochem. Biophys. Res. Commun. 79, 707-712.

28. Wilson, S. P., and Kirshner, N. (1977) Mol. Pharmacol. 13, 382-385.

29. Gratzl, M., and Krieger-Brauer, H. (1981) in Protides of the Biological Fluids (Peeters, H., ed.), Vol. 29, pp. 497-500, Pergamon Press, New York.

30. Krieger-Brauer, H., and Gratzl, M. (1983) J. Neurochem. 41, 1269-1276.

31. Jorgensen, P. L. (1982) Biochim. Biophys. Acta 694, 27-68. 